\title{
The Analysis of Teachers' Lesson Plan through Behavioral Objectives Theory
}

\author{
Intan Septia Latifa \\ Indonesia University of Education, Bandung, Indonesia \\ Intan.latifa22@yahoo.com
}

\begin{abstract}
A lesson plan is a necessary product of lesson study where teachers have the authority to formulate their statements. However, further investigation is necessary to ensure the criteria of lesson plan making are fulfilled. Therefore, this study is objected to analyze teachers' lesson plan through behavioral objectives theory in preparing English learning activities. It employs a qualitative method by applying descriptive study as its framework. Three lesson plans, written by English teachers in senior high schools, were analyzed using descriptive analysis. The data were obtained from document analysis, where theories from Anderson \& Krathwohl (2001), Krathwohl as cited in Allen \& Friedman (2010), Dave (1975), and Schwier as cited in Zerwas (2008) were adapted in analyzing the documents. The result revealed that the objective statements are congruent with the goals of the $\mathbf{2 0 1 3}$ curriculum since the lesson plans reflected learner-centered activities. However, improvements are needed due to completing 'ABCD' and three learning domains in objective statements. The study concludes by suggesting teachers to participate in professional activities including lesson planning to assist them in creating high-quality classroom instruction.

Keywords: behavioral objectives, English, lesson plan, teachers
\end{abstract}

\section{INTRODUCTION}

The change of the education system from the 2006 curriculum or KTSP (School-Based Curriculum) to the 2013 curriculum in Indonesian schools has made massive differences in how lessons are taught. The difference from both curricula is that the latter gives additional times about 4 to 5 hours in a week in which the duration per hour is 45 minutes. The additional time is given to provide the time for implementing a student-centered learning through a scientific approach which is the ultimate goal of the 2013 curriculum.

This reform also influences how teachers prepare the instructional planning of learning activities in the classroom. It is considered important to look at this issue, since it was revealed in a study with 60.000 students that teacher is probably the single most important factor affecting student achievement (Marzano, Marzano, Pickering, 2003:1). In terms of organizing effective lesson, every activity in the classroom has to be arranged in a purposeful way. This makes lesson planning a fundamental stage in teachinglearning cycle.

To accommodate the effective lesson planning, one type of learning objectives called behavioral objectives is assumed to be an appropriate way in setting up English learning activities. Behavioral objectives possess four essential features assisting teachers to create effective learning activities for students, those are; comprehensive (taking cognitive, affective and psychomotor domains in learning), consistency (in line with the aims and goals of the curriculum), attainability (considering students' level, source availability and time allocation), suitability (considering students' need), validity (due to covering aims and goals as whole), and specificity (written explicitly) (Print, 1993).

A relevant research reported by Salman, et al (2012) revealed that the efficacy use of behavioral objectives-based instructional strategy has illustrated effective learning activities for mathematic lesson. The outcomes might be seen in the improvement of students' academic performance at the end of the course. In the other words, it indicated that students irrespective of their levels of education and academic attainment would benefit from effective use of the instructional strategy.

Duchastel \& Merril's work (1973 cited in Salman et al, 2012) states that objectives would certainly make no difference if the students pay no attention to them in the learning situations. Presenting students, therefore with the behavioral objectives of the lesson topic at the beginning of instruction can alert their sensitivity to the learning situation. Referring students to the stated objectives at every stage of information presentation can serve as an evaluating role for teachers teaching as well as students learning, thus, helping to promote learning and students positive attitude towards the subject. However, the study of the use of behavioral objectives in teachers' lesson plan in EFL (English Foreign Language) classroom is still limited. Therefore the goals of this study are to find out whether the lesson plans made by EFL teachers have represented the behavioral objectives theory or not and to examine how far teachers are aware of relying on behavioral objective theory in designing an effective lesson plan in teaching English. Based on the purposes above, the research questions are formulated as follows; (1) Does the lesson show the existence of "ABCD" as a representation of behavioral objectives theory?, (2) Do teachers consider three learning domains (cognitive, affective and psychomotor) in designing a lesson plan?, and (3) What type of learning does the lesson plans reflect?

\section{THEORETICAL FRAMEWORK}

\subsection{Behavioral Objectives theory}

Initially, behavioral objectives are well-known based on the book entitled preparing instructional objectives written by Robert F. Mager published in 1962. Since then, during the 1960s and early 1970s, public school teachers began to regard behavioral objectives as a critical component of their daily 
lesson plan. Margerian model, how they called the model, suggests three specific features of the behavioral objectives; (1) It contains measurable verb or an action verb (observable behavior), (2) It should possess a specification of what is given to students (condition), and (3) It should possess a specification of criteria for competency (standard).

Print (1993) had elaborated the three features of the behavioral objectives. Firstly, condition, the main goal of conditions is the learner knows precisely what is expected due to learning situation through giving activities. So, the expression of a behavioral objective tends to use the word 'given' for beginning the condition statement. The objectives can be formulated, as follows:

Given the formula for the area of the triangles

Given a 20 ounce (565 gram) hockey stick and ball

Moreover, observable behavior refers to what students have to be accomplished to display completion of the objectives. At this point, the selection of the words is important. Taking a look at the table as follow:

Table 1. Selected verbs

\section{Recommended verbs Verbs to avoid}

\begin{tabular}{lllll}
\hline List & $\begin{array}{l}\text { Eval } \\
\text { uate }\end{array}$ & $\begin{array}{l}\text { Distingui } \\
\text { sh }\end{array}$ & Know & Enjoy \\
\hline $\begin{array}{l}\text { Expl } \\
\text { ain }\end{array}$ & State & Construct & $\begin{array}{l}\text { Underst } \\
\text { and }\end{array}$ & Familiarize \\
\hline $\begin{array}{l}\text { Desc } \\
\text { ribe }\end{array}$ & $\begin{array}{l}\text { Sele } \\
\text { ct }\end{array}$ & Calculate & $\begin{array}{l}\text { Appreci } \\
\text { ate }\end{array}$ & Realize \\
\hline $\begin{array}{l}\text { Desi } \\
\text { gn }\end{array}$ & $\begin{array}{l}\text { Iden } \\
\text { tity }\end{array}$ & & Believe & Acquaint \\
\hline
\end{tabular}
be:

The example of a behavioral objectives statement might

Given the formula for the area of a triangle, the student will construct three different examples.....

Given a blank map of Australia, the learner will locate the principal iron-ore deposits...

Furthermore, standards deal with the level of achievement of the students. Three alternative positions are suggested in stating these objectives. First, it should be stated a specific standard followed by acceptable standard. The last is to imply a level of the standard. For example:

Given a set of piece, students will type it within five minutes, with a maximum of ten percent (a specific standard) (Level of standard) errors". Students will bake a sponge, given the correct ingredients, to the teacher's satisfaction)

Since the behavioral objectives have to use a measurable verb in the objective statements, here Schwieras cited in Zerwas (2008) proposed a mnemonic device called 'ABCD' to make sure the objective statements are measurable enough. ABCD stands for A 'audience', B 'behavior', C 'condition' and D 'degree'.

For example:

In the end of the lesson, students [A] are able to identify five names of occupation

\section{[B]after being shown pictures [C]using correct pronunciation $[D]$}

There are three domains of behavioral objectives. Firstly, cognitive domain which refers to intellectual learning and problem solving. Furthermore, Anderson \& Krathwohl (2001) redefined the original levels of knowledge from Bloom's taxonomy into remembering (recalling knowledge from memory), understanding (constructing meaning from different types of functions like written or activities), applying (learned material used through product like presentation or simulation), analyzing (breaking concept into parts and finding out the relationship), evaluating (making judgments based on criteria and standards through checking and critiquing) and creating (putting elements together to form a coherent or functional whole).

Secondly, affective domain refers to the emotion and value system of a person. David Krathwohl is credited with the model that includes five levels: receiving, responding, valuing, organizing, and characterization (Allen \& Friedman, 2010). The first two levels are the process of learning where students are changing in their attitude, responsiveness and attentiveness to learning materials. After students are able to contrast new material with their existing ideas, beliefs and attitude, they can articulate a value in the third value. Moreover, in the fourth level, students make the process of conceptualizing and organizing their value system. In the final level, there is characterization which refers to the way in which an individual is now characterized by a generalized, comprehensive set of values and a philosophy of life and learning.

Thirdly, the psychomotor domain includes physical movement characteristics and motor skill capabilities. Dave (1975) categorized the levels into imitation (observing and patterning behavior after someone else), manipulation (being able to perform certain actions by following instructions and practicing), precision (refining or becoming more exact), articulation (coordinating a series of actions, achieving harmony and internal consistency) and naturalization (having high level performance becomes natural, without needing to think much about it).

\subsection{Lesson Plan}


Sesiorina (2014) did the analysis of teachers' lesson plan in implementing theme-based instruction for teaching English to young learners. There are five aspects of lesson plans analyzed in her research; goals, objectives, activities, media and the assessment. Based on the findings, she drew a conclusion that improvements are needed in composing Behavioral Objectives, encouraging students 'responsibility, and producing learning outcomes.

\section{METHODS}

This research is a qualitative research design aiming at exploring and understanding the issue (Malik \&Hamied: 2016). It applied descriptive study as its framework viewing that everything is potential to provide a clue that reveals a more comprehensive understanding (Bogdan \& Biklen, 2006). The standard used in choosing participants and sites is whether they are "information rich" (Patton cited in Creswell, 2008). Based on the argument, the researcher used Purposeful sampling for this study. The participants of the study were three senior high school teachers who teach English in private and state schools in Bandung. The instrument utilized in this study was a list of action verbs which are divided into three learning domains: cognitive, affective and psychomotor. In collecting the data, three lesson plans used in the second grade students were collected. The main consideration in analyzing the lesson plan was based on a descriptive analysis using Bloom's taxonomy (Anderson \& Krathwohl, 2001; David Krathwohl cited in Allen \& Friedman, 2010; Dave, 1975). The other criteria involved the evaluation of lesson plans using the 'ABCD' method associated with the behavioral objectives (Schwier cited in Zerwas, 2008). This process was done in order to see whether the lesson plans can be considered effective as an instructional plan for learning activities or not.

\section{RESULTS AND DISCUSSION}

A total of four lesson plans were reviewed and the results are presented in each answer to the research questions of this study.

\subsection{The existence of "ABCD" model as a representation of Behavioral objectives theory in the lesson plans}

Table 1 summarizes the findings of the cross-tabulation between the objectives in lesson plans and the 'ABCD' criteria used for evaluating instructional objectives.

Table 2. Calculation of 'ABCD' aspects in the lesson plans

\begin{tabular}{lllll}
\hline & $\begin{array}{l}\text { Audience } \\
\text { 'A' }\end{array}$ & $\begin{array}{l}\text { Behavior } \\
\text { 'B' }\end{array}$ & $\begin{array}{l}\text { Condition } \\
\text { 'C' }\end{array}$ & $\begin{array}{l}\text { Degree } \\
\text { 'D' }\end{array}$ \\
\hline T1 & $16 / 16$ & $15 / 16$ & $10 / 16$ & $5 / 16$ \\
\hline T2 & $12 / 13$ & $12 / 13$ & $11 / 13$ & $3 / 13$ \\
\hline T3 & $15 / 17$ & $11 / 17$ & $16 / 17$ & $1 / 17$ \\
\hline
\end{tabular}

There were 46 objectives designed within three lesson plans, yet only nine objectives represented the behavioral objectives. Overall, those three teachers did not face a big problem in involving Audience and Behavior in the objectives since those are the core of making objectives. However, when 
dealing with the condition, in some activities, T1 did not put Condition in the objectives to specify certain circumstances in which the students should be able to perform certain skills. In this case, the information such as resources, environment, direction, format or datelines are needed. Furthermore, problems are more likely to be experienced in the specification of the Degree of Mastery expected of the learners. In fact, it is important to highlight the degree of accuracy that the learner has to achieve in terms of ensuring whether students' performance is judged proficient or not (O’Bannon, 2008).

The samples of complete and incomplete 'ABCD' can be seen in the following table:

Table 2. Samples of objectives containing 'ABCD' aspects in the lesson plans

Objectives with Students [A] read the descriptive text complete loudly [B] based on what has been 'ABCD; aspects shown in the power point [C] by using correct stressing and intonation [D].

Students $[\mathrm{A}]$ read the random dialogue [B] individually [C] related to their understanding proved by putting the sentences in the right order [D].

Objectives $\quad$ Students [A] look for and make a note without complete of the expression of congratulation [B] 'ABCD; aspects individually $[\mathrm{C}]$.

Students [A] watch a song video of Black or White sung by Michael Jackson [B].

From the finding above, it can be summed up that the teachers still have a lack of comprehension on creating objectives which consist of complete 'ABCD'. They often overlooked Condition as well as Degree of Mastery in their objectives which seem to be the causes of why the activities done by students are difficult to be assessed.

The finding above is also in line with what had been found in the study conducted by Sesiorina (2014) where the problems are related to the completion of ABCD model.

\subsection{Teachers' consideration of three learning domains (cognitive, affective and psychomotor) in designing a lesson plan}

In order to answer the second research question, taking a look at how teachers select the vocabulary in formulating the objectives reveals to which domain is more emphasized by the teachers, whether it is cognitive, affective or psychomotor.

Table 3. Action verb of three learning domains

\begin{tabular}{|c|c|c|c|}
\hline \multicolumn{4}{|c|}{ Action verbs } \\
\hline & Cognitive & Affective & Psychomotor \\
\hline $\mathrm{T} 1$ & $\begin{array}{l}\text { Remembering: } \\
\text { read, mention } \\
\text { Understanding: } \\
\text { expand, describe } \\
\text { Applying: guess }\end{array}$ & $\begin{array}{l}\text { Responding: ask, } \\
\text { perform, report }\end{array}$ & $\begin{array}{l}\text { Imitation: watch, } \\
\text { pay attention, } \\
\text { Precision: } \\
\text { complete } \\
\text { Articulation: use }\end{array}$ \\
\hline
\end{tabular}

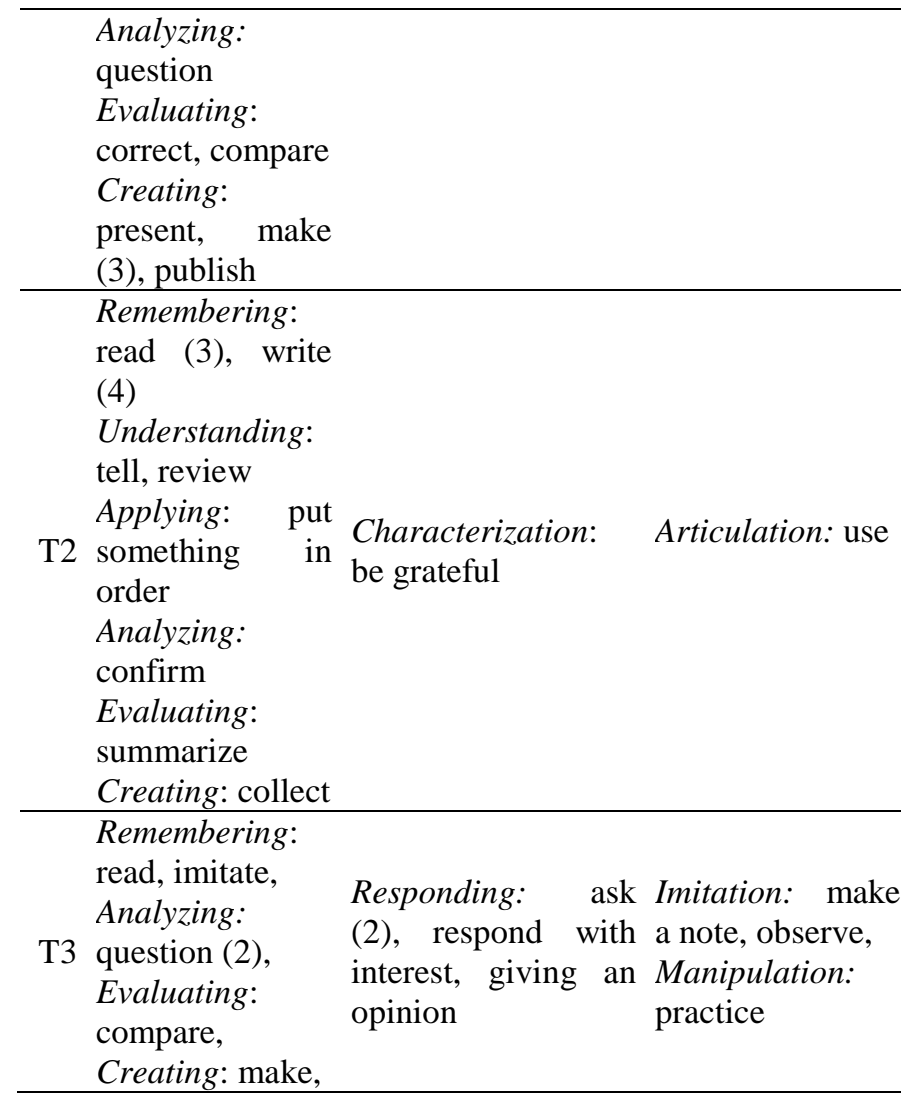

The table above illustrates that cognitive domain gets more attention from the teachers compared to two remaining domains. T1 and T2 completed all levels of knowledge in cognitive domain with the selected action verbs, but they only covered one-third level of knowledge in affective and psychomotor domains. Affective domain appeared at some points when students were fostered to be proactive by showing their critical thinking through questioning and delivering the opinions. In addition, the domain instills value to the students to always be grateful of participating in learning in order to promote positive attitudes toward English learning. Psychomotor domain was adequately sustained through clipping, writing and conversation activities. Although, affective and psychomotor domains got involved in the objective statements, still those two domains appeared less frequently compared to the cognitive domain.

Indeed, the problems related to affective and psychomotor domains have to be the concern among the teachers, curriculum developers and the educators since these two problems also appeared in the previous study conducted by Sesiorina (2014). The teachers neglected to create more activities focusing in these two domains.

\subsection{The type of learning that the lesson plans reflect}

Besides the determining which learning domains were emphasized in the objectives, the selected verbs explained in the previous lesson also revealed how the learning had taken place. In teaching and learning activities, there are three stages of a lesson; lesson introduction-which is commonly 
led by teachers, and lesson development-which is more about how learners take a part in learning cycle. In realizing the action verbs into activities, some conditions are prepared by the teacher. Take a look to the following table:

Table 4. Learning activities reflected in lesson plans

\begin{tabular}{|c|c|c|c|}
\hline $\begin{array}{l}\text { Stage of } \\
\text { lesson }\end{array}$ & Type of activity & $\begin{array}{l}\text { Level of } \\
\text { cognition/ } \\
\text { teaching- } \\
\text { learning } \\
\text { approach }\end{array}$ & $\begin{array}{c}\text { Frequency } \\
\text { of use }\end{array}$ \\
\hline $\begin{array}{c}\text { Lesson } \\
\text { introduction }\end{array}$ & Led by teachers & $\begin{array}{c}\text { Knowledge/ } \\
\text { comprehension }\end{array}$ & 8 \\
\hline $\begin{array}{l}\text { Teacher- } \\
\text { centered } \\
\text { activities }\end{array}$ & $\begin{array}{l}\text { The teacher asks } \\
\text { questions; teacher } \\
\text { allows some } \\
\text { students to } \\
\text { comment/to ask } \\
\text { questions; teacher } \\
\text { gives rewards; } \\
\text { students pay } \\
\text { attention; teacher } \\
\text { gives feedback }\end{array}$ & $\begin{array}{l}\text { Didactic } \\
\text { learning } \\
\text { approach }\end{array}$ & 11 \\
\hline $\begin{array}{l}\text { Learner- } \\
\text { centered } \\
\text { activity }\end{array}$ & $\begin{array}{c}\text { Students ask } \\
\text { questions; } \\
\text { students give } \\
\text { response; } \\
\text { individual work/ } \\
\text { pair work/ group } \\
\text { work; clipping } \\
\text { activities; writing } \\
\text { an essay; making } \\
\text { conversation; } \\
\text { peer assessment. }\end{array}$ & $\begin{array}{l}\text { Learner- } \\
\text { centered } \\
\text { approach; a } \\
\text { scientific } \\
\text { approach }\end{array}$ & 35 \\
\hline
\end{tabular}

The finding presented above reveals that this type of discourse takes the pattern of learner-centered activities. The students are exposed to more dynamic, student-centered and proactive approaches as part of the initial teacher preparation in planning the lesson. The students are also able to explore more in learning activities and get involved nearly in all activities under teachers' control. Therefore, in this type of learning, the roles of teachers are as participant, facilitator, controller, prompter, information supplier and tutor. This type of learning is also congruent with the goal of the 2013 curriculum emphasizing on a student-centered learning through a scientific approach.

\section{CONCLUSION}

From the discussions presented earlier, it can be concluded that the teachers were able to formulate the objective statements which corresponded with the goals of the 2013 curriculum. It can be seen from the activities which mostly involved students in learner-centered activities instead of relying on teacher's talk. However, some inconsistencies occurred when teachers did not succeed in creating learning objective statements with complete 'ABCD' elements consisting of 'Audience, Behavior, Condition and Degree'. The teachers seem to neglect the Degree of Mastery at most compared to the rest elements, causing the statement produced to lose its measurable criteria. On the other words, there is a doubt whether the students' performance is judged proficient or not. Furthermore, the teachers, at the same time, tended to abandon the affective and psychomotor domains which are also as important as cognitive domain. Those three learning domains have to run together to improve knowledge, skills and attitude of the students.

Moreover, dealing with some constraints faced by teachers in formulating the objectives through the behavioral objectives theory, this study proposes a recommendation for engaging in various professional activities including lesson planning that will help teachers lead high-quality classroom instruction.

\section{REFERENCES}

Allen, K. N., \& Friedman, B. D. (2010). Affective learning: A taxonomy for teaching social work values. Journal of Social Work Values and Ethics, 7(2), 1-12.

Anderson, L. W., Krathwohl, D. R., \& Bloom, B. S. (2001). A taxonomy for learning, teaching, and assessing: A revision of Bloom's taxonomy of educational objectives. Allyn \& Bacon.

Bogdan, R., \& Biklen, S. K. (2006). Qualitative research for education: An introduction to theories and methods. USA: Pearson Education, Inc.

Boikhutso, K. (2010). The theory into practice dilemma: Lesson planning challenges facing Botswana studentteachers. Improving Schools, 13(3), 205-220.

Brown, H. D. (2001). Teaching by principles: An interactive approach to language pedagogy (2nd ed.). New York: Addison Wesley Longman, Inc.

Cai, J., Perry, R., \& Wong, N. Y. (2007). What is effective Mathematics teaching? A dialogue between East and West. ZDM-The International Journal on Mathematics Education, 39(4), 265-352.

Creswell, J. W. (2008). Educational research: Planning, conducting, and evaluating quantitative and qualitative research (3rd ed.). New Jersey: Pearson Education International.

Dave, R. H. (1975). Developing and writing Behavior Objectives. Educational Innovators Press.

Harmer, J. (2007).The practice of English language teaching. England: Pearson Education Limited.

Malik, R., \& Hamied, F. A. (2016). Research method. Bandung: UPI PRESS.

Marzano, R. J., Marzano, J. S., \& Pickering, D. J. (2003). Classroom management that works: Research-based strategies for every Teacher. Association for Supervision \& Curriculum Development Publications.

O'Bannon B. (2008). Planning for instruction: writing objectives. Retrieved on April, $11^{\text {th }} 2016$ 
fromhttp://edtech.tennessee.edu/ bobannon/writing_o bjectives.htm\#audience

Print, M. (1993). Curriculum development and design. Malaysia: SRM Production Sevices Sdn Bhd.

Salman, M. F., Yahaya, L. A., Yusuf, A., Ahmed M. A., \& Ayinla, J. O. (2012). Effects of Behavioral Objectivesbased instructional strategy on senior school students' academic performance in Mathematics in Omu-Aran, Nigeria.Journal of Education and Learning, 1(2), 121127.

Sesiorina, S. (2014). The analysis of teachers' lesson plan in implementing theme-based instruction for teaching
English to young Learners. Journal of English and Education. 2(1), 84-95

Woodward, T. (2001). Planning lessons and courses: Designing consequences of work for the language classroom. Cambridge: Cambridge University Press.

Warren, K. (1999). A study on Behavioral Objectives: Do they affect learning. Education and Human Development. Unpublished Master's Thesis.

Zerwas, Stephan. (2008). Looking at the first year objectively. Annual Conference on First Year Assessment. Retrieved on April, $11^{\text {th }} 2016$ from http://sc.edu/fye/events/presentation/national_assessme nt/2008/files/Zerwas 